\title{
Evaluation of Photosynthetic, Enzymatic Activities and Lipoperoxidation Level in Two Species of Bryophytes Exposed to Sencorate
}

\author{
Fadila Khaldi $^{1,2, *}$, Khouloud Boukehili², Nedjoud Grara ${ }^{3}$ \\ ${ }^{1}$ Laboratory of Sciences and Technology of Water and Environment, Department of Biology, Faculty of Nature and Life Sciences, University \\ of Mohamed Cherif Messaadia, Souk-Ahras, Algeria \\ ${ }^{2}$ Department of Biology, Faculty of Nature and Life Sciences, University of Mohamed Cherif Messaadia, Souk-Ahras, Algeria \\ ${ }^{3}$ Department of Biology, Faculty of Nature and Life Sciences and Earth Sciences and Universe, University 8 May 1945, Guelma, Algeria
}

\section{Email address:}

khaldifad@yahoo.fr (F. Khaldi)

${ }^{*}$ Corresponding author

\section{To cite this article:}

Fadila Khaldi, Khouloud Boukehili, Nedjoud Grara. Evaluation of Photosynthetic, Enzymatic Activities and Lipoperoxidation Level in Two Species of Bryophytes Exposed to Sencorate. International Journal of Ecotoxicology and Ecobiology. Vol. 2, No. 2, 2017 , pp. 87-97.

doi: $10.11648 /$ j.ijee. 20170202.15

Received: May 14, 2017; Accepted: June 1, 2017; Published: July 21, 2017

\begin{abstract}
To better understand the behavior of the plants towards xenobiotics, two species of bryophytes (Orthotrichum affine and Scleropodium purum), bioindicators of the region of Souk Ahras (Algeria) which have properties completely different (classification, reproductive cycle...) are treated under hydroponic conditions by 125, 250, 500, 1000 and $1500 \mathrm{mg} / \mathrm{L}$ of Sencorate herbicide (Metribuzin) for 3, 7, 14 and 21 days. A measure of some physiological, biochemical and enzymatic parameters characteristic of oxidative stress have allowed us to evaluate not only the effect of Sencorate herbicide but also the behavior of the two species with respect to pollution. Statistical analysis of the results showed significant differences between the treated and control samples for the majority of parameters studied, with lower levels of chlorophyll pigments $(a, b, a+b)$ accompanied by increased levels of proline, total protein and soluble carbohydrates. Depletion of GSH at the beginning of treatment, accompanied by an increase in Malondialdehyde MDA levels were observed with low activity of the enzyme biomarkers Catalase and Ascorbat peroxydase (CAT and APX), which reflects the high tolerance of these species to pollutants.
\end{abstract}

Keywords: Orthotrichum affine, Scleropodium purum, Sencorate, Oxidative Stress, CAT, APX, MDA

\section{Introduction}

Since a few decades, the growth and diversity of human activities were accompanied by the release into the environment of quantities of xenobiotic harmful to human health [1]. In several countries, the accumulation of pollutants in the ecosystems led, to the deterioration of the quality of the environment, to the decline of forests and to the decrease of the agricultural productivity $[2,3]$. The analysis of the mechanisms of response to oxidative stress or oxidative stress - xenobiotic interactions may therefore provide a better understanding of the processes of response to xenobiotics [4].

Generally, the increased activity of enzymes involved in defense reactions seems to be related to the species or to the plant variety, to the physiological conditions of the plant, or still to the type of oxidative stress applied [5]. The exacerbated metabolism of herbicides is the best known mechanism [6]. The increased activity of degradation is the result of the increasing affinity of these enzymes to their target, or the surexpression of the genes coding for these enzymes, and a better perception of the active molecule of herbicide [7]. In addition, the exposure of photosynthetic organisms to certain environmental pollutants causes an overproduction of reactive oxygen species (ROS), causing oxidative stress which can lead to death [8]. Many organic xenobiotics, such as herbicides, can cause an overproduction of ROS. This accumulation may be due to an inhibition of electron transport related to photosynthesis process, and therefore to an inhibition of the photosystem activity [9].

During their migration, herbicides, such as all the foreign 
substances, can be biotransformed. In order to act, they are required to enter into plants, and thus find themselves in contact with metabolizing enzymes. As a result in some rare exceptions near, herbicides are effectively more or less rapidly metabolized [10]. Generally, the increased activity of enzymes involved in defense responses appear to be related to the species or plant variety, the physiological conditions of the plant, or the type of oxidative stress applied [10].

This study has for objective the determination of the fate of an herbicide which is widely used in agriculture, on bryophytes that have been selected as biological models and the capacity of these selected models to adapt to the presence of increasing concentrations of xenobiotic. In this work, we will try to make our contribution on the use of plants as bioindicators of pollution and studying their behavior towards harmless molecules but at the same time controversial likely:
Sencorate herbicide.

\section{Material and Methods}

\subsection{Geographical Location of the Sampling Site}

The choice of our sampling site is focused on the region of Ain seynour. Situated in the northwest of Souk-Ahras and in the southeast of Guelma (Figure 1).Bordered in the north by daïra Mechroha $(7 \mathrm{~km})$, in the east by the daïra Ouled Driss $(14 \mathrm{~km})$, in the west by the municipality Hennancha, and in the south by Souk Ahras city $(13 \mathrm{~km}))$.The geographical coordinates of the site are $36^{\circ} 19^{\prime} 11$ " north and $7^{\circ} 52^{\prime} 13$ " East, with a latitude of 36.319773 and Longitude of 7.870218 ( in decimal degrees).

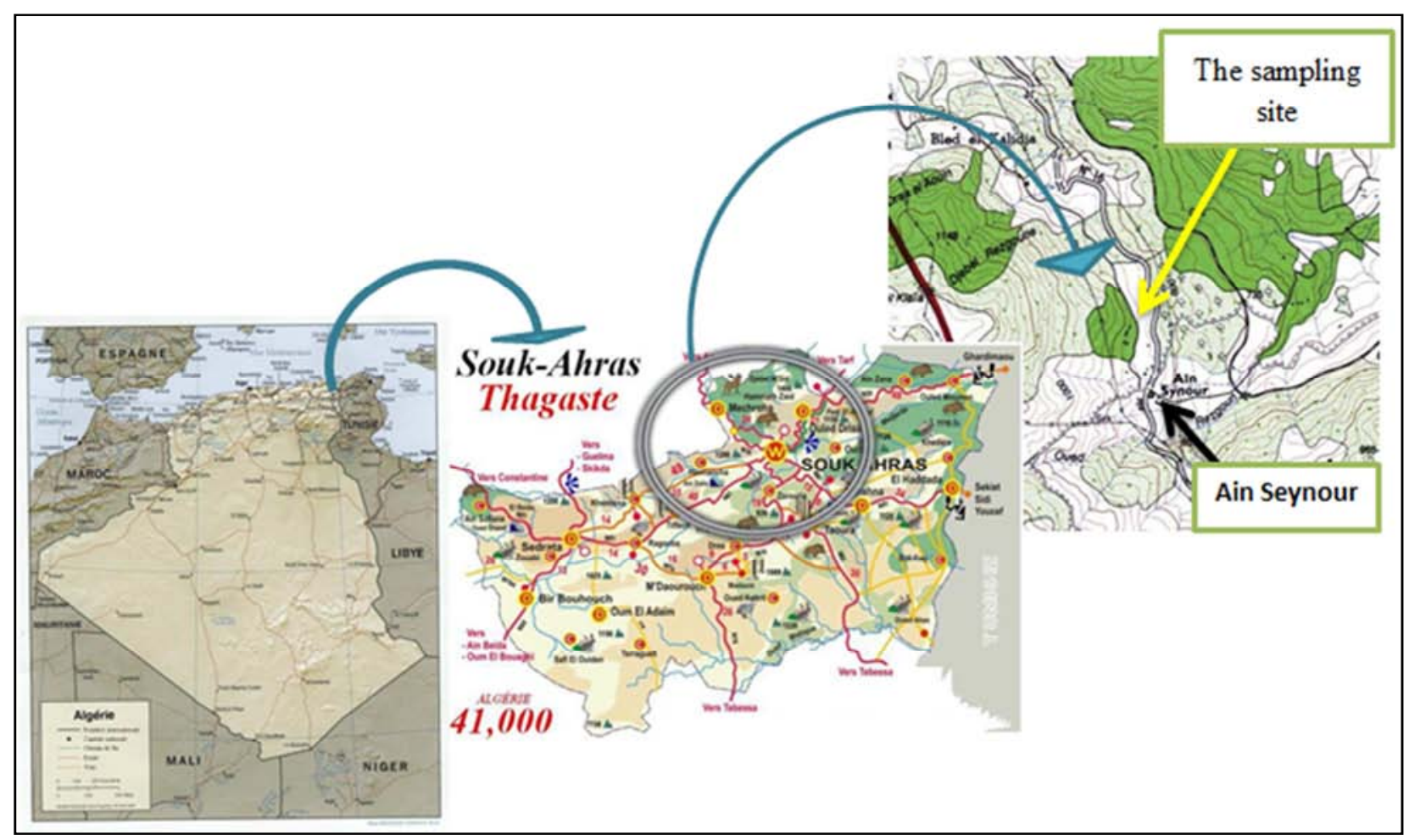

Figure 1. Geographical location of the sampling site "Ain Seynour" (Direction of Agriculture, SOUKAHRAS, 2013).

\subsection{Harvest Bioindicator Species}

A survey of bryophytes was made on the region of Ain Seynour, where we have chosen two species of bryophytes: Orthotrichum affine and Scleropodium purum. Thalli of both species were collected on the bark of trees of several stations under standardized conditions (height of levies from 1.50 to 2 $\mathrm{m}$ above the ground) [11]. Sampling was effected in January and February 2013.

O. affine is the most common Orthotrichum on trees and shrubs in the districts where the air is pure. It is often abundant on the branches and trunks of a wide variety of trees, particularly ash (Fraxinus excelsior), hazel (Corylus avellana), sycamore (Acer pseudoplatanus) and willow (Salix) [12]. S. purum fits very well in shaded areas and can also develop in moderately lit habitats. In addition, this species develops in sites where the temperature is optimum for its development. This species grows on a substrate can be highly acidic or alkaline $(4.1<\mathrm{pH}<7)$ and humidity of habitat is moderately moist to moderately dry [13].

\subsection{Bryophyte Treatment}

The Sencorate herbicide is used for absorption samples of both species (Orthotrichum affine, Scleropodium purum) and is dissolved in distilled water at concentrations of 125, 250, 500,1000 and $1500 \mathrm{mg} / \mathrm{L}$. Approximately, $1 \mathrm{~g}$ of thallus of each species is soaked in $100 \mathrm{ml}$ of prepared solutions during four periods of treatment: 3, 7, 14 and 21 days [14]. Metribuzin $\mathrm{C}_{8} \mathrm{H}_{14} \mathrm{~N}_{4} \mathrm{OS}$ (active compound of Sencorate ) is an inhibitor of photosystem and disrupts plant growth. 


\subsection{Determination of Chlorophyll, Proline, Total Protein and Soluble Carbohydrates}

The method used for extraction of chlorophyll is the traditional method established by Holden [15] which is a maceration of the plant in acetone. For the determination of proline, the technique used is that of Monneveux and Nemmar [16]. The proteins are assayed by the Bradford method [17] using BSA as standard. Soluble carbohydrates were determined by the method of Schields and Bunnet [18] using anthrone in sulfuric acid.

\subsection{Enzyme Assay Method of Catalase}

CAT activity is performed according to the method of Cakmak and Horst [19]. The decrease in absorbance is recorded for three minutes at $240 \mathrm{~nm}$ and a molar extinction coefficient $\varepsilon=39400 \mathrm{M}^{-1} . \mathrm{cm}^{-1}$.L. To a final volume of $3 \mathrm{ml}$, the reaction mixture contains: $100 \mu$ of the crude enzyme extract, $50 \mu \mathrm{l}$ of hydrogen peroxide $\left(\mathrm{H}_{2} \mathrm{O}_{2}\right)$ to $0.3 \%$ and $2850 \mu \mathrm{l}$ of phosphate buffer $(50 \mathrm{mM}, \mathrm{pH}=7.2)$. The reaction is started by the addition of hydrogen peroxide.CAT activity is expressed as $\mu \mathrm{mol} / \mathrm{min} / \mathrm{mg}$ of proteins.

\subsection{Enzyme Method Assay of Ascorbat Peroxydase}

APX activity is carried out according to the protocol adopted by Nakano and Azada [20]. The final reaction volume of $3 \mathrm{ml}$ contains: $100 \mu \mathrm{l}$ of enzyme extract, $50 \mu \mathrm{l}$ of $0.3 \% \mathrm{H}_{2} \mathrm{O}_{2}$ and $2850 \mu \mathrm{l} \mathrm{NaK}$ phosphate-ascorbate buffer (50 $\mathrm{mM} \mathrm{NaK}, 0.5 \mathrm{mM}$ ascorbate, $\mathrm{pH}=7.2$ ). The reading is taken at $290 \mathrm{~nm}$ for $1 \mathrm{~min}$ and for a molar extinction coefficient $\varepsilon$ $=2800 \mathrm{M}^{-1} \mathrm{~cm}^{-1}$.L.APX activity is expressed as $\mu \mathrm{mol} / \mathrm{min} /$ $\mathrm{mg}$ of proteins.

\subsection{Determination of Glutathione}

GSH was assayed by the method of Weckberker and Cory [21], based on measuring the absorbance of the 2-nitro-5 mercapturic resulting from the reduction of the acid 5-5 'thiol-bis-2- nitrobenzoic acid (DTNB) by the thiol groups ($\mathrm{SH})$ glutathione. The results were expressed as nmole $/ \mathrm{mg}$ of proteins.

\subsection{Malondialdehyde Accumulation}

Lipid peroxidation was estimated by changing the content of malondialdehyde according to the method described by [22]. The absorbance is read at $532 \mathrm{~nm}$. MDA was calculated using the extinction coefficient $155 \mathrm{mM}^{-1} \mathrm{~cm}^{-1}$. The results were expressed as nmole $/ \mathrm{mg}$ of proteins.

\subsection{Statistical Analysis}

The treatment and the data analysis was realized using a specialized statistical software, which is Statistica 8.0 (Statsoft). Our statistical analysis articulates on the following points:

a) A statistical description was given for each studied variable by calculating the median $(\tilde{x})$;

b) Comparison of several groups: the non-parametric test of Kruskal Wallis was used to test the effect "dose" of Sencorate herbicide compared to batch control (comparison-species);

c) In addition, the Kruskal Wallis test was followed by a post-hoc analysis presented by the multiple comparison test ( $\mathrm{z}$ 'values) or pairwise comparison to classify different doses according to "herbicide" effect;

d) Comparison of two groups: the test U of Mann-Whitney was used to test the global effect inter-species of Sencorate herbicide of the four periods of exposure;

e) Finally, we analyzed by the coefficient of correlation of Spearman, the neatness of the linear relations between all the quantitative variables used in this work.

The conditions of applications of the statistical tests were verified and respected according to the recommendations indicated in several statistical works as: (Dagnelie, 2006, 2007; Scherrer, 2007, 2009.

\section{Results}

The results indicate that chlorophyll pigments, metabolites and enzymatic biomarkers show varying patterns depending on the exposure time in both species.

Figure 2 ( $a, b, c)$ shows that, from the 3 days of treatment, the content of chlorophyll pigment increased significantly compared to the control for the majority of applied doses especially in S. purum. After 7 days of exposure, the results show a disturbance of the levels of these pigments in the samples of both species treated with this herbicide. In the last two periods of treatment, there was a progressive decrease in both species where the application of $1500 \mathrm{mg} / \mathrm{L}$ of herbicide has the lowest chlorophyll content (21days).

During the treatment of 3 and 7 days, significant increases in levels of proline and total protein were observed in both species (Figure $3 \mathrm{a}$ and $\mathrm{b}$ ), especially with the highest herbicide dose $(1500 \mathrm{mg} / \mathrm{L})(38,47 \mu \mathrm{g} / \mathrm{mg}$ of FM was recorded for proline of the species $O$. affine (treatment 3 days)), then a decrease was noted from the 14th day, in which the application of high concentration of herbicide registering the weakest levels of these two metabolites, except the rate of total protein its increase in $S$. purum at the 21th day (Figure 3a).

Regarding the species $O$. affine, the levels of soluble carbohydrates increased significantly during the first days of treatment, but they are still lower than controls except the concentration $1500 \mathrm{mg} / \mathrm{L}$ (3 days), and the concentrations 500, 1000 and $1500 \mathrm{mg} / \mathrm{L}$ (7 days) that have higher levels than controls. After 14 days of treatment, the levels recorded a decreasing profile that develops into a complete decline during the 21 days of treatment (Figure $3 \mathrm{c}$ ).

By cons, in the species $S$. purum, the measured of rate soluble carbohydrates increased significantly after 3 days of exposure, then decreases gradually at the same time, according concentrations of herbicide, from the $7^{\text {th }}$ and 7 th days. However, at the end of treatment the rate returns to its pattern of increase (21days) (Figure 3c).

Figure 4 shows the analysis of the enzymatic activities 
involved in the management process of oxidative stress (CAT and APX) throughout the treatment not show significant differences compared to controls. Except, the APX of the species $O$. affine (3days, Figure 4b) and the CAT of the species $S$. purum (21 days, Figure 4a), that show a growing profile in the samples treated with high concentrations of herbicide ( 500, 1000 and $1500 \mathrm{mg} / \mathrm{L}$ ).

Figure (5a) illustrates that the decrease in GSH rate is dose-dependent during the 3 days of treatment in both species (21.01 $\mu \mathrm{mol} / \mathrm{mg}$ of proteins for $O$. affine and $6.81 \mu \mathrm{mol} /$ $\mathrm{mg}$ of proteins for $S$. purum with $1500 \mathrm{mg} / \mathrm{L})$. After 7 days of exposure, a significant increase of these biomarkers was noted. Starting from 14 days of treatment, the rate continues to increase until it reaches its maximum value $(36.39 \mu \mathrm{mol} /$ $\mathrm{mg}$ of proteins) with the highest concentration $(1500 \mathrm{mg} / \mathrm{L})$ in $O$. affine. While, in $S$. purum this biomarker is a reverse path and decreases by dose (Figure 5a).

Indeed, significant differences and dose -dependent progressive increase in the rate of MDA are noted in both species of bryophytes during 3, 7 and 14 days of treatments, where a maximum rate is observed $(2.59 \mu \mathrm{mol} / \mathrm{mg}$ of proteins) in the samples of $S$. purum treated with $1500 \mathrm{mg} / \mathrm{L}$ of Sencorate after 7 days of exposure. However, the 21days of treatment shows a non- significance in $O$. affine, while a reduction in the rate with high concentrations (500, 1000 and $1500 \mathrm{mg} / \mathrm{L}$ ) was observed in S. purum (Figure 5b).
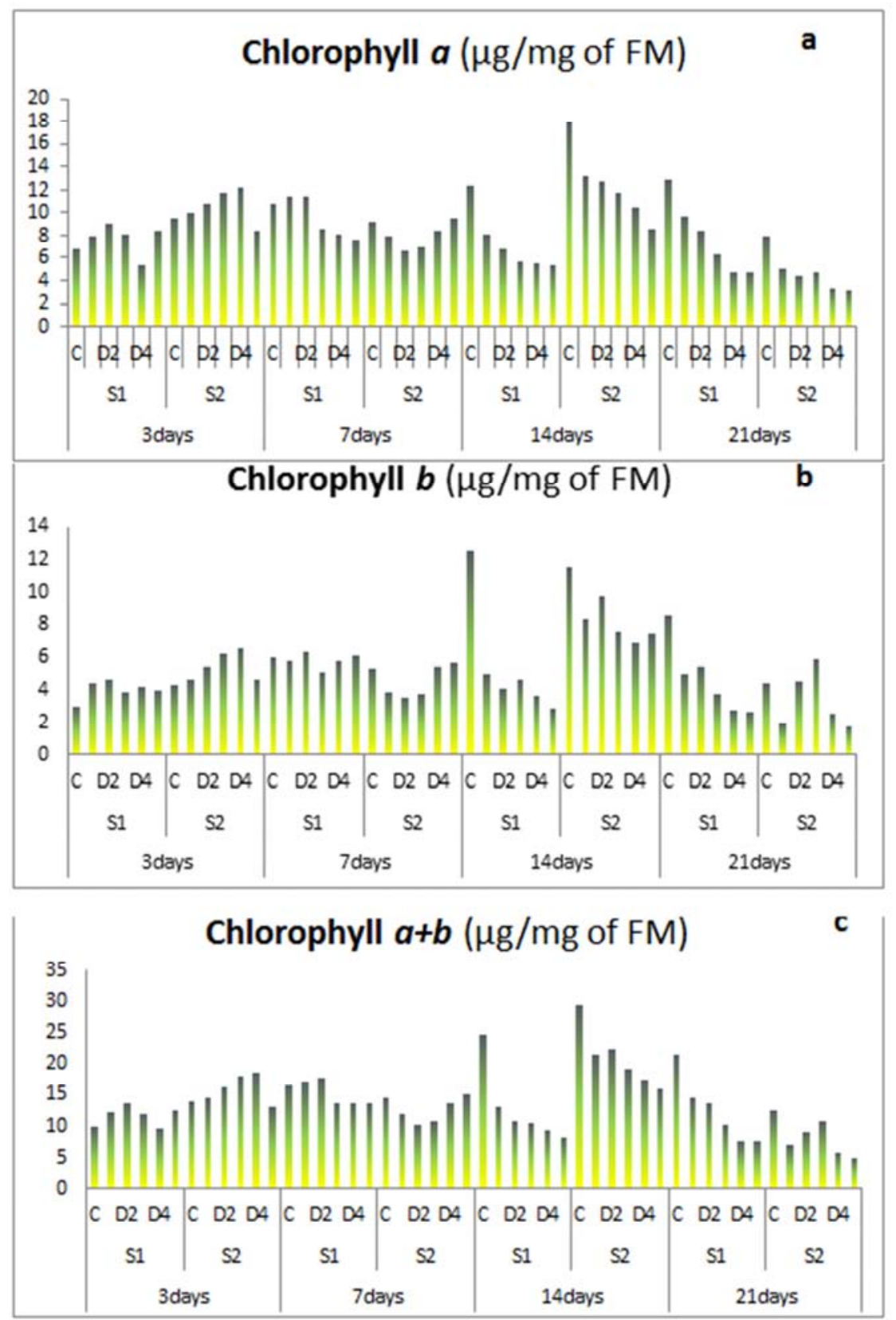

Figure 2. Effect of Sencorate herbicide on chlorophyll pigment levels $a(a), b(b)$ and $a+b$ (c) (median) in the two species (O. affine (S1) and S. purum (S2)) after 3, 7, 14, 21 days of exposure (Kruskal Wallis test, $n=30$ ). C: Control, D1: 125, D2: 250, D3: 500, D4: 1000 and D5: 1500 mg / L. (FM:fresh matter). 


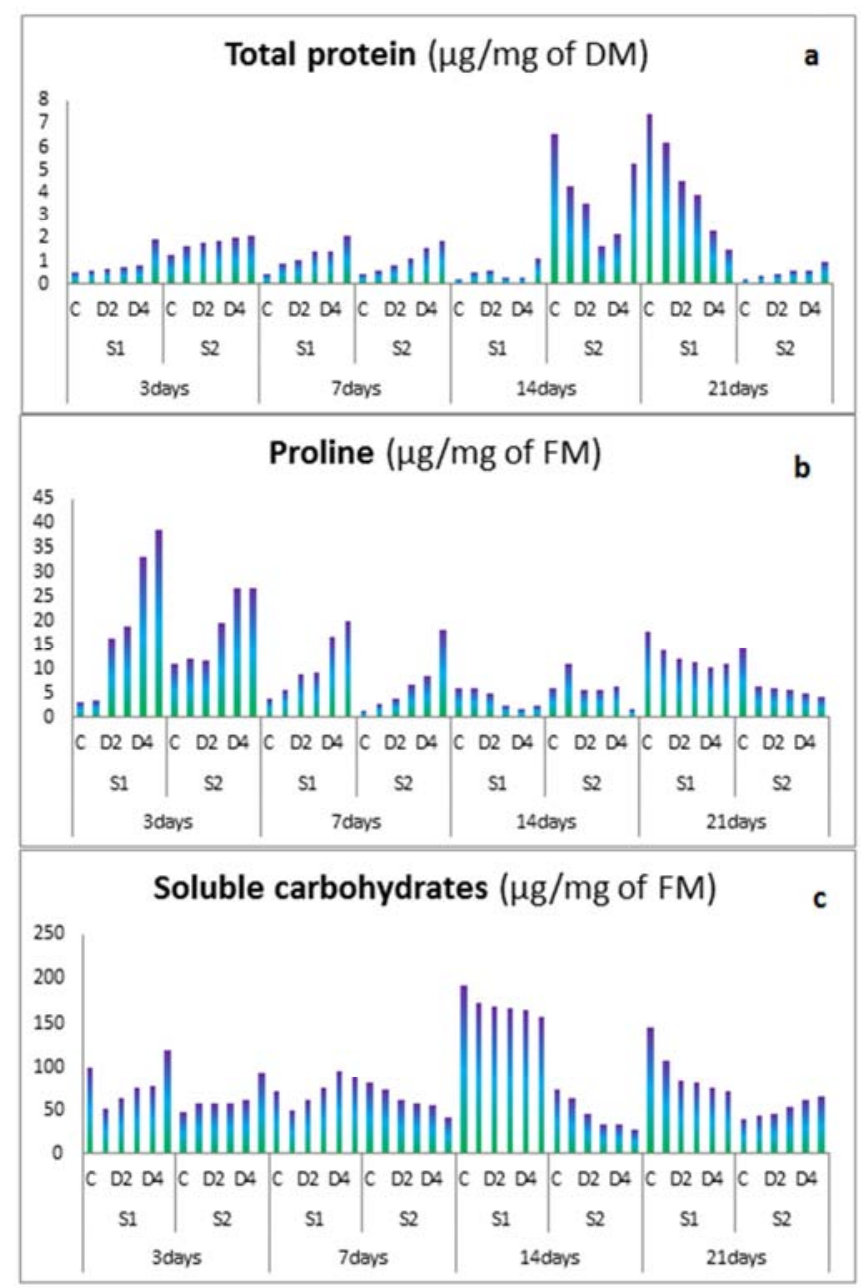

Figure 3. Effect of Sencorate herbicide on the level of metabolites (total protein (a), soluble carboydrates (b), proline (c)) (median) in the two species (O. affine (S1) and S. purum (S2)) after 3,7,14,21 days of exposure (Kruskal Wallis test, $n=30$ ). C: Control, D1: 125, D2: 250, D3: 500, D4: 1000 and D5: 1500 mg / L. (DM:dry matter, FM:fresh matter).

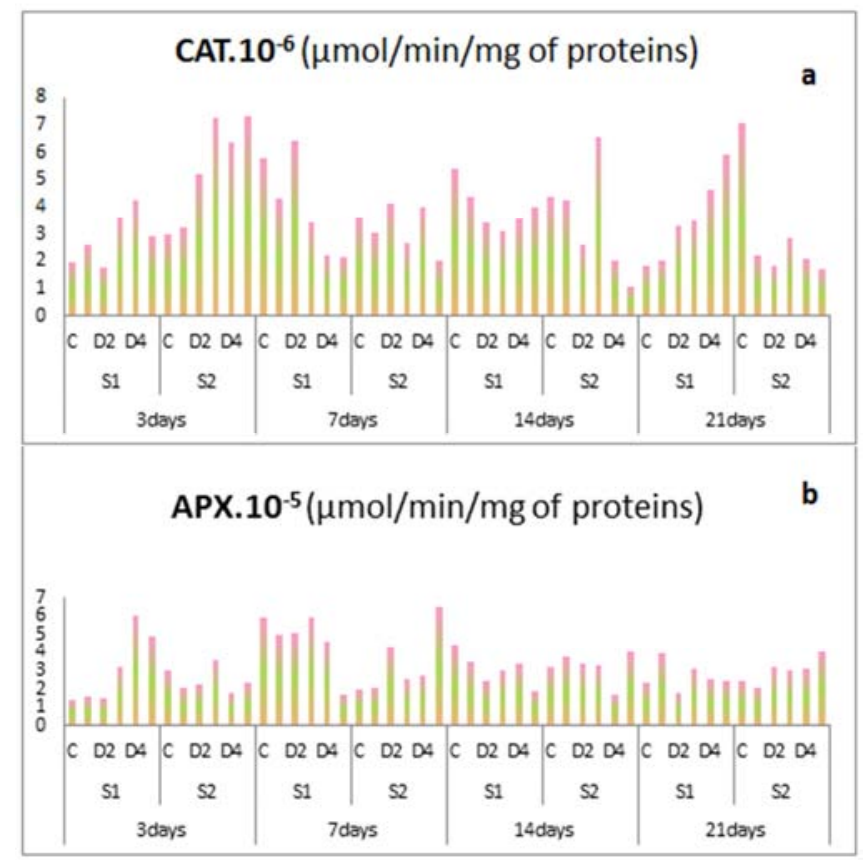

Figure 4. Effect of Sencorate herbicide on the enzymatic activity (CAT (a) and APX (b)) (median) in the two species (O. affine (S1) and S. purum (S2))after 3,7,14,21 days of exposure (Kruskal Wallis test, $n=30$ ). C: Control, D1: 125, D2: 250, D3: 500, D4: 1000 and D5: $1500 \mathrm{mg} / \mathrm{l}$. 


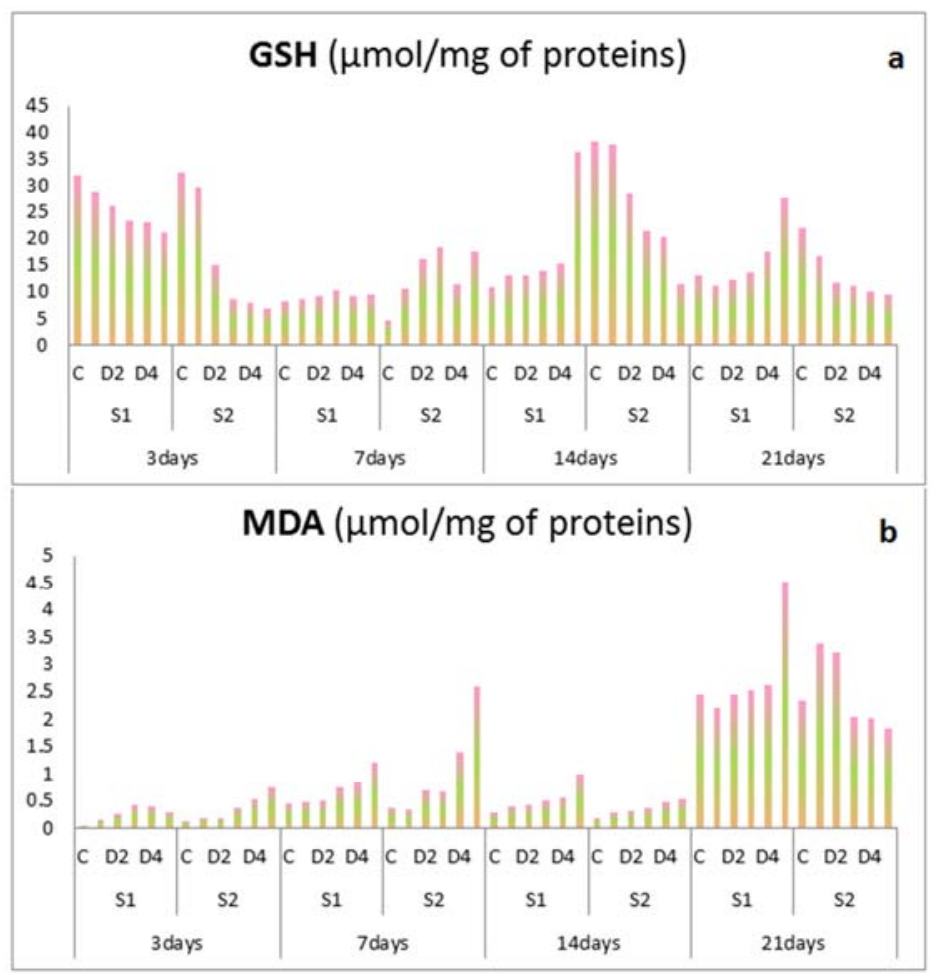

Figure 5. Effect of Sencorate on levels of glutathione $(G S H)(a)$, malondialdehyde accumulation $(M D A)$ (b) in the two species $(O$. affine (S1) and S. purum (S2)) after 3, 7, 14, and 21 days of exposure (Kruskal Wallis test, $n=30$ ). C: Control, D1: 125, D2: 250, D3: 500, D4: 1000 and D5: $1500 \mathrm{mg} / \mathrm{L}$.

Table 1. The results of "Kruskal Wallis" Test of the effect of Sencorate on $O$. affine (H and $p$ values) for the four periods of treatment.

\begin{tabular}{|c|c|c|c|c|c|c|c|c|}
\hline \multirow{2}{*}{ O. affine } & \multicolumn{2}{|l|}{ 3days } & \multicolumn{2}{|l|}{ 7days } & \multicolumn{2}{|l|}{ 14days } & \multicolumn{2}{|l|}{ 21days } \\
\hline & H & p & H & $\mathbf{P}$ & H & $\mathbf{P}$ & $\mathbf{H}$ & $\mathbf{P}$ \\
\hline Chl a & 28,1019 & 0,0000 & 27,6374 & 0,0000 & 28,2258 & 0,0000 & 28,2258 & 0,0000 \\
\hline Chl b & 25,6245 & 0,0001 & 26,1452 & 0,0001 & 28,2258 & 0,0000 & 28,1019 & 0,0000 \\
\hline $\mathrm{Chl} \mathrm{a+b}$ & 27,0748 & 0,0001 & 26,5536 & 0,0001 & 28,2258 & 0,0000 & 28,2258 & 0,0000 \\
\hline Prol & 26,7097 & 0,0001 & 21,6897 & 0,0006 & 24,1878 & 0,0002 & 26,1866 & 0,0001 \\
\hline Prot & 23,6128 & 0,0003 & 27,0189 & 0,0001 & 26,6109 & 0,0001 & 28,2258 & 0,0000 \\
\hline Carb & 28,2258 & 0,0000 & 28,2258 & 0,0000 & 28,2384 & 0,0000 & 28,2321 & 0,0000 \\
\hline APX & 12,0607 & 0,0340 & 3,4185 & 0,6358 & 4,0009 & 0,5493 & 1,4584 & 0,9178 \\
\hline GSH & 27,3587 & 0,0000 & 16,7444 & 0,0050 & 26,1361 & 0,0001 & 23,4981 & 0,0003 \\
\hline MDA & 23,8697 & 0,0002 & 24,8813 & 0,0001 & 18,1344 & 0,0028 & 9,7587 & 0,0824 \\
\hline
\end{tabular}

After four periods of exposure, table 1 show that there are significant differences in the species $O$. affine between simples treated with Sencorate and controles for the majority of parameters (chlorophyll pigments $(a, b$ and $a+b)$, total protein, proline, soluble carbohydrates and GSH $(\mathrm{p} \leq 0.001)$.
However, CAT and APX are not significant- except the 3days of treatment for the APX ( $U=12.0607, p=0.0340)$-. In addition, MDA indicates non-significance differences during the 21 days of treatment $(\mathrm{U}=9.7587, \mathrm{p}=0.0824)$.

Table 2. The results of "Kruskal Wallis" Test of the effect of Sencorate on S. purum (H and p values) for the periods of treatment.

\begin{tabular}{|c|c|c|c|c|c|c|c|c|}
\hline \multirow{2}{*}{ S.purum } & \multicolumn{2}{|l|}{ 3days } & \multicolumn{2}{|l|}{ 7days } & \multicolumn{2}{|l|}{ 14days } & \multicolumn{2}{|l|}{ 21days } \\
\hline & $\mathbf{H}$ & $\mathbf{p}$ & H & $\mathbf{p}$ & $\mathbf{H}$ & $\mathbf{P}$ & H & $\mathbf{p}$ \\
\hline Chl a & 28,2258 & 0,0000 & 28,2258 & 0,0000 & 28,2258 & 0,0000 & 28,2258 & 0,0000 \\
\hline Chl b & 27,4207 & 0,0000 & 27,5858 & 0,0000 & 27,7097 & 0,0000 & 27,7097 & 0,0000 \\
\hline Chl a+b & 28,2258 & 0,0000 & 28,2258 & 0,0000 & 28,2258 & 0,0000 & 28,2258 & 0,0000 \\
\hline Prol & 23,4389 & 0,0003 & 24,3231 & 0,0002 & 20,6604 & 0,0009 & 27,1782 & 0,0001 \\
\hline Prot & 23,8884 & 0,0002 & 27,5239 & 0,0000 & 28,2572 & 0,0000 & 25,7049 & 0,0001 \\
\hline Carb & 28,2321 & 0,0000 & 27,9038 & 0,0000 & 28,1814 & 0,0000 & 28,0564 & 0,0000 \\
\hline CAT & 7,3897 & 0,1932 & 1,9290 & 0,8589 & 9,4439 & 0,0926 & 11,2245 & 0,0471 \\
\hline APX & 8,1143 & 0,1501 & 1,4403 & 0,9199 & 8,2206 & 0,1445 & 2,1243 & 0,8317 \\
\hline GSH & 25,7432 & 0,0001 & 26,0168 & 0,0001 & 26,1303 & 0,0001 & 27,4826 & 0,0000 \\
\hline MDA & 25,5254 & 0,0001 & 26,3626 & 0,0001 & 22,6361 & 0,0004 & 23,5497 & 0,0003 \\
\hline
\end{tabular}


After four periods of exposure, table 2 show that there are significant differences in the species $S$. purum between simples treated with Sencorate and controles for the majority of parameters (chlorophyll pigments ( $a, b$ and $a+b)$, total protein, proline, soluble carbohydrates, GSH and MDA ( $\mathrm{p} \leq$ 0.001). However, CAT and APX are not significant. During the 21days of treatment, we demonstrated significant differences for all parameters. So that APX indicates nonsignificance $(\mathrm{U}=2.1243, \mathrm{p}=0.8317)$
Tables 3 and 4 illustrates the application of multiple comparison test ( $\mathrm{z}^{\prime}$ values) Kruskal Wallis. This test is used to classify Sencorate doses of herbicide and group those that have the same effect on the two species (O. affine, S. purum). According to the data in these two tables, we found that the most common classification separates witnesses from high concentrations (1000 and $1500 \mathrm{mg} / \mathrm{L})$ while low concentrations $(125,250$ and $500 \mathrm{mg} / \mathrm{L})$ are comparable to controls.

Table 3. The ranking of Sencorate herbicide concentrations in O. affine (multiple comparison (z'values)). (The grading is done only for significant results).

\begin{tabular}{|c|c|c|c|c|}
\hline O. affine & 3days & 7days & 14days & 21days \\
\hline $\mathrm{Chl} \mathrm{a}$ & D4 C D1 D3 D5 D2 & D2 D1 C D3 D4 D5 & C D1 D2 D3 D4 D5 & C D1 D2 D3 D4 D5 \\
\hline $\mathrm{Chl} \mathrm{b}$ & 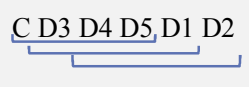 & D2 D5 C D1 D4 D3 & C D1 D2 D3 D4 D5 & C D2 D1 D3 D4 D5 \\
\hline $\mathrm{Chl} \mathrm{a+b}$ & D4 C D1 D3, D5 D2 & D2 D1 C D4 D3 D5 & C D1 D2 D3, D4 D5 & C D1 D2 D3 D4 D5 \\
\hline Prol & C D1 D2 D3 D4 D5 & C D1 D2 D3 D4 D5 & D1 C D2 D3 D5 D4 & C D1 D2 D3 D5 D4 \\
\hline Prot & $\underbrace{\mathrm{C} \text { D1 D2 D3 D4 D5 }}$ & C D1 D2 D3 D4 D5 & C D4 D3 D1 D2 D5 & C D1 D2 D3 D4 D5 \\
\hline Carb & D1 D2 D3 D4 C D5 & D1 D2 C D3 D5 D4 & C D1 D2 D3 D4 D5 & C D1 D2 D3 D4 D5 \\
\hline GSH & C D1 D2 D3 D4 D5 & C D1 D2 D4 D3 D5 & C D1 D2 D3 D4 D5 & C D1 D2 D3 D4 D5 \\
\hline MDA & CD1 D2 D5 D3 D4 & C D1 D2 D3 D4 D5 & C D1 D2 D3 D4 D5 & --- \\
\hline
\end{tabular}

Table 4. The ranking of Sencorate herbicide doses in S. purum (multiple comparison (z'values)). The grading is done only for significant results.

\begin{tabular}{|c|c|c|c|c|}
\hline S. purum & 3days & 7days & 14days & 21days \\
\hline Chl a & D5 C D1 D2 D3 D4 & D5 C D1 D4 D3 D2 & C D1 D2 D3 D4 D5 & C D1 D2 D3 D4 D5 \\
\hline Chl b & C D5 D1 D2 D3 D4 & D2 D3 C D1 D4 D5 & C D2 D1 D3 D5 D4 & D3 D2 C D4 D1 D5 \\
\hline $\mathrm{Chl} \mathrm{a+b}$ & D5 C D1 D2 D3 D4 & D5 C D1 D4 D3 D2 & C D2 D1 D3 D4 D5 & C D3 D1 D2 D4 D5 \\
\hline Prol & C D1 D2 D3 D4 D5 & C D1 D2 D3 D4 D5 & $\underbrace{\mathrm{D} 1 \mathrm{C} \text { D2 D3 D4 D5 }}$ & C D1 D2 D3 D4 D5 \\
\hline Prot & CD1 D2 D3 D4 D5 & C D1 D2 D3 D4 D5 & C D5 D1 D2 D4 D3 & C D1 D2 D3 D4 D5 \\
\hline Carh & CD1 D2 D3 D4 D5 & C D1 D2 D3 D4 D5 & C D1 D2 D3 D4 D5 & C D1 D2 D3 D4 D5 \\
\hline (and & L & L & LL & 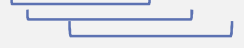 \\
\hline GSH & C D1 D2 D3 D4 D5 & C D1 D4 D2 D3 D5 & C D1 D2 D3 D4 D5 & C D1 D2 D3 D4 D5 \\
\hline MDA & C D1 D2 D3 D4 D5 & C D1 D2 D3 D4 D5 & C D1 D2 D3 D4 D5 & D1 D2 C D3 D4 D5 \\
\hline
\end{tabular}


To compare the differences between the two species and their behavior against the treatment with the herbicide

(Sencorate), we applied the non-parametric Mann-Whitney U test and the results of $\mathrm{U}$ and $\mathrm{p}$ are given in Table 5.

Table 5. Inter-Species comparison (values of $U$ and $p$ ) as a function of exposure time (Mann-Whitney $U$ test).

\begin{tabular}{|c|c|c|c|c|c|c|c|c|}
\hline \multirow{2}{*}{$\mathbf{S 1 / S 2}$} & \multicolumn{2}{|l|}{ 3days } & \multicolumn{2}{|l|}{ 7days } & \multicolumn{2}{|c|}{ 14days } & \multicolumn{2}{|c|}{ 21days } \\
\hline & $U$ & $p$ & $U$ & $p$ & $U$ & $\boldsymbol{P}$ & $U$ & $p$ \\
\hline Chl $a$ & 38,0 & 0,000000 & 229,0 & 0,001086 & 80,0 & 0,000000 & 136,0 & 0,000003 \\
\hline Chl $b$ & 74,0 & 0,000000 & 83,0 & 0,000000 & 140,0 & 0,000005 & 279,0 & 0,011467 \\
\hline Chl $a+b$ & 30,0 & 0,000000 & 207,0 & 0,000327 & 125,0 & 0,000002 & 199,0 & 0,000207 \\
\hline Prol & 418,0 & 0,636141 & 283,5 & 0,013832 & 215,0 & 0,000512 & 116,0 & 0,000001 \\
\hline Prot & 102,5 & 0,000000 & 391,0 & 0,383056 & 0,0 & 0,000000 & 0,0 & 0,000000 \\
\hline Carb & 200,0 & 0,000219 & 280,0 & 0,011959 & 0,0 & 0,000000 & 0,0 & 0,000000 \\
\hline APX & 443,5 & 0,923442 & 391,0 & 0,383056 & 440,0 & 0,882466 & 407,5 & 0,529783 \\
\hline GSH & 250,0 & 0,003108 & 180,0 & 0,000066 & 223,0 & 0,000791 & 304,0 & 0,030888 \\
\hline MDA & 372,5 & 0,251882 & 430,0 & 0,767468 & 274,0 & 0,009267 & 388,5 & 0,363223 \\
\hline
\end{tabular}

After 3 days of exposure, the application of this test shows that there are significant differences between the two species for the majority of parameters. While, proline $(\mathrm{U}=418.0, \mathrm{p}=$ $0.63), \operatorname{APX}(\mathrm{U}=443.5, \mathrm{p}=0.92)$ and $\operatorname{MDA}(\mathrm{U}=372.5, \mathrm{p}=$ $0.25)$ are not significant.

During the 7 days of treatment, we have found significant differences between the two species for chlorophyll pigments $(a, b$ and $a+b)$, and GSH ( $\mathrm{p}<0.001)$. However, proline (U $=283.5, \mathrm{p}=0.013)$ and soluble carbohydrates $(\mathrm{U}=280.0, \mathrm{p}$ $=0.011)$ indicates a lower significance. The latter is absent for CAT $(U=434.0, p=0.813), \operatorname{APX}(U=391.0, p=0.383)$ and MDA $(\mathrm{U}=430.0, \mathrm{p}=0.767)$.

After 14 and 21 days of exposure, the results show that the two species (O. affine and $S$. purum) are statistically different for the majority of parameters, except CAT, APX and MDA of the last treatment.

To complete the statistical analysis, we analyzed the correlation between quantitative variables: chlorophyll pigments $(a, b$ and $a+b)$, metabolites (proline, total protein and soluble carbohydrates), enzymatic biomarkers (CAT, APX, GSH, MDA) in both species Orthotrichum affine (Table 6) and Scleropodium purum (Table 7).

Table. 6. Spearman correlation matrix of the various parameters measured in the species $O$. affine.

\begin{tabular}{|c|c|c|c|c|c|c|c|c|c|c|}
\hline O. affine & Chl a & Chl b & Chl $\mathbf{a}+\mathbf{b}$ & Prol & Prot & Carb & CAT & APX & GSH & MDA \\
\hline Chl a & 1 & & & & & & & & & \\
\hline Chl b & 0,802 & 1 & & & & & & & & \\
\hline $\mathrm{Chl} \mathrm{a+b}$ & 0,946 & 0,935 & 1 & & & & & & & \\
\hline Prol & 0,214 & 0,172 & 0,209 & 1 & & & & & & \\
\hline Prot & 0,053 & 0,012 & 0,084 & 0,599 & 1 & & & & & \\
\hline Carb & $-0,122$ & 0,001 & $-0,081$ & $-0,202$ & $-0,189$ & 1 & & & & \\
\hline CAT & $-0,029$ & $-0,046$ & $-0,050$ & $-0,039$ & $-0,112$ & $-0,014$ & 1 & & & \\
\hline GSH & $-0,593$ & $-0,775$ & $-0,729$ & $-0,079$ & $-0,129$ & 0,026 & $-0,053$ & $-0,242$ & 1 & \\
\hline MDA & $-0,204$ & $-0,053$ & $-0,097$ & 0,206 & 0,715 & 0,014 & 0,001 & $-0,053$ & $-0,218$ & 1 \\
\hline
\end{tabular}

Table 6 shows that the levels of chlorophyll $a, b$ and $(a+b)$ pigments of the species $O$. affine are highly correlated $(\mathrm{r}=$ 0.80) Conversely, they are moderately anti- correlated with glutathione. In addition, there is a reasonable correlation of total protein content with proline $(60 \%)$ and with MDA levels $(72 \%)$.

Table 7. Spearman correlation matrix of the various parameters measured in the species S. purum.

\begin{tabular}{|c|c|c|c|c|c|c|c|c|c|c|}
\hline S. purum & Chl a & Chl b & Chl $\mathbf{a}+\mathbf{b}$ & Prol & Prot & Carb & CAT & APX & GSH & MDA \\
\hline Chl a & 1 & & & & & & & & & \\
\hline Chl b & 0,820 & 1 & & & & & & & & \\
\hline $\mathrm{Chl} \mathrm{a+b}$ & 0,973 & 0,917 & 1 & & & & & & & \\
\hline Prol & 0,412 & 0,177 & 0,318 & 1 & & & & & & \\
\hline Prot & 0,740 & 0,757 & 0,777 & 0,267 & 1 & & & & & \\
\hline Carb & $-0,009$ & $-0,203$ & $-0,101$ & $-0,021$ & $-0,017$ & 1 & & & & \\
\hline APX & $-0,028$ & 0,058 & 0,016 & $-0,072$ & 0,066 & $-0,045$ & $-0,177$ & 1 & & \\
\hline GSH & 0,408 & 0,281 & 0,366 & 0,122 & 0,269 & $-0,389$ & $-0,001$ & 0,012 & 1 & \\
\hline MDA & $-0,696$ & $-0,416$ & $-0,631$ & $-0,078$ & $-0,462$ & $-0,251$ & $-0,108$ & 0,009 & $-0,332$ & 1 \\
\hline
\end{tabular}

However, the results for $S$. purum (Table 7 ) show that the chlorophyll pigments are highly correlated with a coefficient of determination of $82-97 \%$ and they are correlated with the rate of total protein and anti- correlated with the levels of 
MDA. Thus, there is low negative correlation between total proteins and MDA.

In sum, it can be noted that:

- Different chlorophyll pigments are highly correlated in both species;

- The rate of total protein in $O$. affine is correlated with Proline and MDA levels, while that of $S$. purum is correlated with chlorophylls ( $a, b$ and $a+b)$;

- MDA is strongly correlated with the total protein content in the species $O$. affine, but they are negatively correlated in the second;

- In the species $O$. affine, the APX is weakly correlated with chlorophyll $a, b$ and $a+b$ and negatively correlated with GSH. However, these parameters are not correlated in the species $S$. purum.

\section{Discussion}

The concurrent use of several biomarkers is essential to assess the effects of complex different classes of pollutants. In fact, the study of the biological responses of organisms submitted to different environmental conditions is being considered as a successful approach for the assessment of environmental quality [27].

In the specialized literature, there are especially data concerning the action of herbicides on the metabolic processes of wild plants [28], but there is a lack of research on the biochemical response of plants grown in this factor. The present work follows the influence of herbicide Sencorate, on the major metabolites, physiological and enzymatic of two species of bryophytes in the presence of increasing concentrations of herbicides.

The chlorophyll content is often used to assess the impact of many environmental stresses. The exposure of two species of bryophytes during all periods of treatment $(3,7,14$ and 21 days) to this herbicide has shown significant differences in chlorophyll ( $a, b$ and $a+b)$. This effect is consistent with previous work [29, 30] and according to the result of [31]. Sencorate Herbicide modifies the chlorophyll content and, again, chlorophyll $b$ appears to be less sensitive than chlorophyll $a$, to the toxicity of this herbicide in the species (Scleropodium purum ).

Our results are in agreement with those of [32], put in evidence a disruptive effect of ammonium on the biosynthesis of chlorophyll, as well as disturbance of the external and internal morphology of chloroplasts leaves. Other authors [33] reported frequent degeneration of the amount of chlorophyll and carotenoids in plants exposed to different concentrations of heavy metals.

The strong accumulation of pollutants (fertilizers) found in thalli foams is probably responsible for the production of free radicals, as evidenced by the significant increase in MDA, this can cause partial destruction of antioxidants that are chlorophyll $a$ [34]. The accumulation of amino acids due to environmental stress can be explained by the breakdown of certain proteins sensitive to stress or by the synthesis of new amino acids [35]. This increase is consistent with a protective function of membranes against free radical attack, agreeing with the observations of [36] suggest that the proline reacts with hydroxyl radicals to generate nontoxic hydroxyproline and those of [37] and [38] show that a singlet oxygen scavenging by proline.

Our results show a significant increase in the amount of proteins that can be explained by the fact that the presence of xenobiotic inside plant tissues stimulates protein synthesis of many enzymes among others, those involved in detoxification, which is in perfect agreement with the results of [33], which shows that the accumulation of proteins is proportional to that of the metal.

Our results are also consistent with the work of [39], who found a significant increase in amino acid levels and protein in green beans (Phaselous vulgaris L.cv. strike) treated with $24 \mathrm{mM}$ of $\mathrm{NH}_{4} \mathrm{NO}_{3}$. Thus, our previous work [40] showed an increased rate of proline and total protein in foams (Leucodon sciuroides ) and in lichens ( Ramalina farinacea) treated with different concentrations of the fertilizer $\mathrm{NH}_{4} \mathrm{NO}_{3}$.

Endogenous levels of soluble carbohydrates, as well as their nature vary depending on various parameters, such as the organ, the age, the cycle, and the environmental conditions [41]. Overall, they reflect the balance between photosynthesis and plant growth. Moreover, even if these nutritional traits are essential, they appear yet variables within different accessions of the same species, which can be explained by the metabolic changes in production systems or the use of these carbon compounds [42]. However, these amplitudes of variations are limited compared to those obtained by the provision of exogenous carbohydrates.

To fight against oxidative damage, plants set up enzymatic antioxidants defense systems that play a role in regulating the levels of ROS [14]. The subsequent application of the Sencorate herbicide treatment does not significantly affect the enzymatic biomarkers (CAT, APX). Our study of the response of two species of bryophytes to an herbicide treatment showed that defense mechanisms were weakly activated where there have been no significant differences in all periods of treatment (3, 7, 14 and 21 days). Our results confirm the resistance of the foam to the herbicide, but also highlights the fact that they are very dependent in this case of the nature of the substrate particulary (Sencorate).

GSH is a substrate of seleno - dependent glutathione peroxidase (GPX). This antioxidant enzyme uses GSH as the primary source of hydrogen [43]. In our work, we demonstrated a dose -dependent decrease in GSH in the presence of this herbicide (3 days of treatment) in both species. This depletion can be explained by the direct link of glutathione to the xenobiotic atoms because the glutathione has a carboxylic acid group, an amine group, a sulfhydryl group ( - $\mathrm{SH}$ ) and two peptide bridges may be involved in reactions with other atoms. Its functional - $\mathrm{SH}$ group would play an important role in binding to the xenobiotic [44]. These results are consistent with the work of [45, 46, 47, 48].

Lipid peroxidation is a mechanism of cell damage well known and used as an indicator of oxidative stress. The lipoperoxides are derived from polyunsaturated fatty acids. 
They are unstable and decompose to form carbonyl compounds, the most abundant is the malondialdehyde (MDA). This is why the MDA is often used as an indicator of lipid peroxidation [13]. The malondialdehyde (MDA), which is a good marker of lipid peroxidation, is increased significantly in both species of bryophytes treated with different concentrations of Sencorate herbicide.

\section{Conclusion}

The different components of the environment react differently to pollution, the lower plants often have physiological, morphological and structural alterations, even before the appearance of symptoms of intoxication less humans. The results obtained in the present study showed marked differences in photosynthetic parameters, enzymatic biomarkers and lipid peroxidation level in two species of bryophytes (Orthotrichum affine and Scleropodium purum), exposed to Sencorate herbicide. Finally, it will be of interest to measure the other enzymes involved in the detoxification and particularly: GPX and SOD in these species of bryophytes exposed to Sencorate herbicide and to initiate an ultra-structural study of our biological models in the presence or absence of the pollutant (herbicide).

\section{References}

[1] M. Gérin, P. Gosselin, C. Viau, P. Quénel and E. Oewailly. Environnement et santé publique. Québec, Edisem Inc., pp. 641-779. 2003.

[2] A.H. Chapelka and L.I. Samuelson. Ambient ozone effects on forest trees of the eastern United States, a review. New Phytol, 139: 91 -108. 1998.

[3] A. Wahid. Influence of atmospheric pollutants on agriculture in developping countries: a case study with three new wheat varieties in pakistan. Sei. Total Environ., 371: 304-313. 2006.

[4] F. Ramel. Implication des sucres solubles dans les réponses aux stress xénobiotique et oxydatif chez Arabidopsis thaliana. Thèse de Doctorat de l'Université de Rennes I, 231 p. 2009.

[5] D. Souguir. Modification métaboliques, moléculaires et génotoxicité induites par le cadmium chez Vicia faba. Thèse de Doctorat de l'Université d'Auvergne Clemont Ferrand-II, 207 p. 2009.

[6] L. L. Van Eerd, R. E. Hoagland, R. M. Zablotowicz and J. C. Hall. Pesticide metabolism in plants and microorganisms. Weed Science, 51: 472-95. 2003.

[7] J. S. Yuan, P. J. Tranel and C. N. Stewart. Non-target-site herbicide resistance: a family business. Trends in Plant Science, 12: 6-13. 2007.

[8] Y. E. Chao, M. Zhang, S. K. Tian, L. L. Lu and X. E. Yang. Differential generation of hydrogen peroxide upon exposure to zinc and cadmium in the hyperaccumulating plant specie (Sedum alfredii Hance). Journal of Zhejiang UniversityScience, B 9: 243-249. 2008.

[9] C. Fufezan, A. W. Rutherford and A. Krieger-Liszkay. Singlet oxygen production in herbicide-treated photosystem II. FEBS
Letters, 532: 407-410. 2002.

[10] R. Scalla. Devenir des herbicides et modifications métaboliques dans les plantes transgéniques. INRA-ENSAT UR 556. Toulouse. Cedex 09. 2002.

[11] A. Semadi and S. Deruelle. Détection de la pollution plombique à l'aide de transplants lichéniques dans la region de Annaba (Algérie). Pollution Atmosphérique, 86-102. 1993.

[12] S. Bosanquet. Orthotrichum -Britain's bristle-mosses. British Wildlife, 187-194. 2009.

[13] J. Faburé. Étude de l'accumulation et des effets des composés organiques volatils (BTEX) chez les bryophytes. Thèse de Doctorat de l'Université de LILLE NORD, France, 299 p. 2009.

[14] F. Khaldi, H. Djebar, R. Rouabhi and M.R. Djebar. Cellular Response of a Pollution Bioindicator Model (Ramalina farinacea) Following Treatment with Fertilizer (NPKs). American-Eurasian Journal of Toxicologic Sciences, 1 (2): 6973. 2009.

[15] M. Holden. Chlorophylls in chemistry and biochemistry of plant pigment. $2^{\text {nd }}$ Edition Academie press, New York, pp. 133. 1975.

[16] P. H. Monneveux and M. Nemmar. Contribution à l'étude de la résistance à la sécheresse chez le blé tendre. Etude de l'accumulation de la proline au cours du cycle de développement. Agronomie. 17 p. 1986.

[17] M. M. Bradford. A rapid and sensitive method for the quantification of microgram quantities of protein utilizing the principle of protein-dye binding. Anal. Biochem., 72: 248-254. 1976.

[18] R. Schields and W. Burnett. Determination of protein bound carbohydrate in serum by a modified anthrone method. Anal. Chem., 32: 885-886. 1960.

[19] I. Cakmak and W. J. Horst. Effect of aluminium on lipid peroxidation, superoxide dismutase, catalase and peroxidase activities in root tips of soybean (glycine max). Physiol.Plant, 83:463-468. 1991.

[20] Y. Nakano and K. Azada. Purification of ascorbate peroxidase in spinach chloroplasts: its inactivation in ascorbate depleted medium and reactivation by monodehydroascorbate radical. Plant Cell Physiol., 28: 131-140. 1987.

[21] G. Weckberker and G. Cory. Ribonucléotide reductase activity abd growth of glutathione depleted mouse leukemial 1210 cells in vitro. Cacer letters, 40: 257-264. 1988.

[22] Alia, K. V. S. K. Prasad and S. P. Pardha. Effect of zinc on free radical and proline in Brassica juncea and Cajanus cajan. Phytochemestry, 39: 5-47. 1995.

[23] P. Dagnelie. Statistique théorique et appliquée. Tome 1. Statistique descriptive et bases de l'inferérence statistique. De Boeck et Larcier, Bruxelles, 511p. 2006.

[24] P. Dagnelie. Statistique théorique et appliquée. Tome 2. Inférence statistique à une et à deux dimentios. De Boeck et Larcier, Bruxelles, 734p. 2007.

[25] B. Scherrer. Biostatistique. Volume 1. Gaetan Morin, 832p. 2007.

[26] B. Scherrer. Biostatistique. Volume 2. Gaetan Morin, 592p. 2009. 
[27] Z. Bouraoui, M. Banni, J. Ghedira, C. Clerandeau, J.F. Narbonne and H. Boussetta. Evaluation of enzymatic biomarkers and lipoperoxidation level in Hediste diversicolor exposed to copper and benzo [a] pyrene. Ecotoxicol. Environ.Saf., 72(7): 1893-1898. 2009.

[28] P. Böger and K. Wakabayashi. Peroxidizing herbicides. Springer Verlag, Berlin, 405 p. 1999.

[29] M. D. Groppa, M. P. Ianuzzo, M. L. Tomaro and M. P. Benavides. Polyamine metabolism in sunflower plants under long-terme cadmium or copper stress. Amino Acids, 32: 265275. 2007a.

[30] M. D. Groppa, M. L. Tomaro and M. P. Benavides. Polyamines and heavy metal stress: the antioxidant behavior of spermine in cadmium- and copper-treated wheat leaves. BioMetals, 20: 185-195. 2007b.

[31] B. Mysliwa-Kurdziel, M. N. V. Prasad and K. Strzalka. Heavy metal influence on the light phase of photosynthesis. In: Prasad M. N. V., Strzalka K. (eds) Physiology and Biochemistry of Metal Toxicity and Tolerance in Plants, Kluwer Academic Publishers, Netherlands, pp. 229-255. 2002.

[32] G. S. Puritch and A. V. Barker. Structure and function of leaf tomato chloroplasts during ammonium toxicity. Plant. Physiol., 42: 1229-1238. 1967.

[33] S. S. Shraddha, R. Rohit and S. S.Sarita. Response of antioxidants in sunflower (Helianthus annuus L.) grown on different amendments of tannery sludge: its metal accumulation potential. Chemosphere, 57 (11): 1663-1673. 2004.

[34] F. Khaldi. Mécanisme d'action des polluants chimiques industriels (engrais et NOx) sur des bioindicateurs de pollution (mousses et lichens). Thèse de doctorat de l’Université Badji Mokhtar, Annaba, 198 p. 2013.

[35] L. B. Pena, L. A. Pasquini, M. L. Tomaro and S. M. Gallego. Proteolytic system in sunflower (Helianthus annuus L.) leaves under cadmium stress. Plant Sci., 171: 531-537. 2006.

[36] N. Smirnoff and O. J. Cumbes. Hydroxyl radical scavenging activity of compatible solutes. Phytochem., 28: 1057-1060. 1989.

[37] P. Alia, Mohanty and J. Matysik. Effect of proline on the production of singlet oxygen. Amino Acids, 21: 195-200. 2001.

[38] J. Matysik, Alia, B. Bhalu and P. Mohanty. Molecular mechanisms of quenching of reactive oxygen species by proline under stress in plants. Current Science, 82: 525-532. 2002.

[39] E. Sanchez, R. M. Rivero, J. M. Ruiz and L. Romero. Changes in biomass activity and protein concentration in roots and leaves of green bean plant (Phaseolus vulgaris L.cv. Strike) under high $\mathrm{NH}_{4} \mathrm{NO}_{3}$ application rates. Scientia Horticulturae, 99: 273-248. 2004.

[40] F. Khaldi. Toxicité du nitrate d'ammonium $\mathrm{NH}_{4} \mathrm{NO}_{3}$ sur trois modèles biologiques: les paramécies, les mousses et les lichens. Effet sur leur métabolisme respiratoire. Mémoire de Magister en Biochimie Appliquée. Université Badji Mokhtar, Annaba, 86 p. 2003.

[41] A. M. Smith and M. Stitt. Coordination of carbon supply and plant growth. Plant Cell and Environment, 30: 1126-1149. 2007.

[42] J. M. Cross, M. Von Korff, T. Altmann, L. Bartzetko, R. Sulpice, Y. Gibon, N. Palacios and M. Stitt. Variation of enzyme activities and metabolite levels in 24 Arabidopsis accessions growing in carbon-limited conditions. Plant Physiolog., 142: 1574-1588. 2006.

[43] G. T. Saez, W. H. Bannister and J. V. Bannister. Free radicals and thiolcompounds: the role of glutathione against free radical toxicity. In: Vina, J. (Ed.) Glutathione Metabolism and Physiological Functions, CRC Press, Boca Raton, pp. 237254. 1990.

[44] M. E. Anderson. Determination of glutathione and glutathione disulfide in biological samples. Method. Enzymol., 113: 548554. 1985.

[45] T. Cao, L. Y. Ni and P. Xie. Acute biochemical responses of a submersed macrophyte, Potamogeton crispus L., to high ammonium in an aquarium experiment. J. Freshwater Ecol., 19: 279-284. 2004.

[46] J. L. Freeman, M. W. Persans, K. Nieman, C. Albrecht, W. Peer, I. Pickering and D.E. Salt. Increased glutathione biosynthesis plays a role in nickel tolerance in Thlaspi nickel hyperaccumulators. Plant Cell., 16: 2176-2191. 2004.

[47] F. Khaldi, H. Berrebbah and M. R. Djebar. Study of Atmospheric Pollution emitted rated A plant of Fertilizers (Algeria) by the use of bioindicator plants: lichens. Advances in Environmental Biology, 6 (5): 1823-1833. 2012a.

[48] F. Khaldi, H. Berrebbah and M.R. Djebar. Toxic Effect of Fertilizers on Inferior Plants Resed as Biological Models. International Conference on Applied Life Sciences (ICALS2012). Turkey. September 10-12, pp 205-210. 2012 b. 